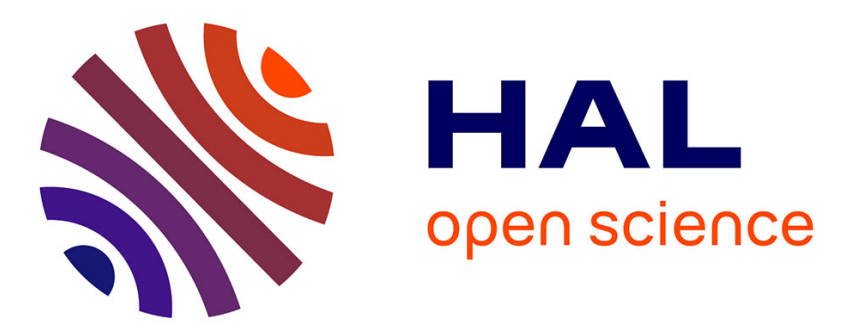

\title{
Intra-articular injections in thumb osteoarthritis: A systematic review and meta-analysis of randomized controlled trials
}

Sabine Trellu, Sabrina Dadoun, Francis Berenbaum, Bruno Fautrel, Laure

Gossec

\section{To cite this version:}

Sabine Trellu, Sabrina Dadoun, Francis Berenbaum, Bruno Fautrel, Laure Gossec. Intra-articular injections in thumb osteoarthritis: A systematic review and meta-analysis of randomized controlled trials. Joint Bone Spine, 2015, 82 (5), pp.315-319. 10.1016/j.jbspin.2015.02.002 . hal-01132938

\section{HAL Id: hal-01132938 \\ https://hal.sorbonne-universite.fr/hal-01132938}

Submitted on 18 Mar 2015

HAL is a multi-disciplinary open access archive for the deposit and dissemination of scientific research documents, whether they are published or not. The documents may come from teaching and research institutions in France or abroad, or from public or private research centers.
L'archive ouverte pluridisciplinaire HAL, est destinée au dépôt et à la diffusion de documents scientifiques de niveau recherche, publiés ou non, émanant des établissements d'enseignement et de recherche français ou étrangers, des laboratoires publics ou privés. 


\title{
Intra-articular injections in thumb osteoarthritis: a systematic review and meta-analysis of randomized controlled trials.
}

\author{
S. Trellu¹, S. Dadoun¹, F Berenbaum², B. Fautrel1, L. Gossec ${ }^{1}$
}

1 Sorbonne Universités, UPMC Univ Paris 06, GRC-UPMC 08 (EEMOIS), Institut Pierre Louis d'Epidémiologie et de Santé Publique, Paris, France; AP-HP, Pitié Salpêtrière Hospital, Department of rheumatology, Paris, France

2 Sorbonne Universités, UPMC Univ Paris 06, INSERM UMR-S938, AP-HP, Saint-Antoine Hospital, Department of rheumatology, Paris, France

\section{CORRESPONDING AUTHOR FOR REPRINTS}

Pr. Laure Gossec, Hôpital Pitié-Salpêtrière, Service de Rhumatologie, 47-83, boulevard de l'Hôpital - 75013 Paris France

laure.gossec@psl.aphp.fr

Tel: +33142178421

Fax: $+33-142177959$

\section{Word count: 2140 (13972 characters)}

ABSTRACT: 215 words, 1498 characters

Objectives: The objective was to assess the efficacy of intra-articular injections of corticosteroids or hyaluronic acid in thumb osteoarthritis.

Methods: A systematic review of the literature was performed until August 2014. All controlled trials reporting the efficacy on pain, functional capacity and pulp pinch force of hyaluronic acid or corticosteroids in thumb osteoarthritis were selected. Pooled standardised response means (SRMs) were assessed by meta-analysis.

Results: Six trials were included and contributed to 3 meta-analyses (hyaluronic acid versus placebo, corticosteroids vs placebo and hyaluronic acid vs corticosteroids). Among the 428 patients included, 169 were treated with hyaluronic acid, 147 with corticosteroids and 74 with placebo. Versus placebo at week 12, hyaluronic acid (2 trials, 148 patients) lead to better functional capacity (SRM -1.14 [-1.69; -0.60]) with no difference on pain; corticosteroids (2 trials, 164 patients) lead to no difference in pain or function. When comparing hyaluronic acid vs corticosteroids (4 trials, 304 patients), no difference was evidenced until week 12. At week 24, pain was significantly lower in the corticosteroids group (SRM $1.44[0.14 ; 2.74]$ ) and pulp pinch force higher in the hyaluronic acid group (SRM -0.75 [-3.87; -1.97]).

Conclusion: This meta-analysis shows great heterogeneity. Hyaluronic acid may be useful to increase functional capacity and corticosteroids to decrease pain in thumb osteoarthritis at week 24.

Key words Thumb osteoarthritis, intra-articular injection, corticosteroids, hyaluronic acid, pain, functional capacity

\section{Introduction}

Osteoarthritis $(\mathrm{OA})$ of the carpo-metacarpal joint of the thumb is a common condition, affecting at least $30 \%$ of women over the age of 65 (1). The life impact and disability associated to hand OA 
are significant. Hand disability is frequent in patients suffering from thumb $O A$, with a reduction of grip strength and difficulty writing or fingering small objects $(2,3)$.

Few treatments have been assessed in thumb OA. According to the European League Against Rheumatism (EULAR) and the American College of Rheumatology (ACR) recommendations, the optimal management of thumb $O A$ requires a combination of non-pharmacological measures such as local application of heat or splints, and pharmacological treatment modalities $(4,5)$. Local treatments are preferred to systemic treatments. For intra-articular injections, experts' opinion differs in thumb OA $(4,5)$. Evidence of efficacy of intra-articular hyaluronic acid or corticosteroid injections in thumb OA is scarce, while largely investigated in hip and knee (6 - 10). For example in knee OA, intra-articular corticosteroids are reported to decrease pain (10) whereas hyaluronic acid injection seems to relieve pain and to improve functional capacity (7-9). Both of these modalities are recommended by international associations for the treatment of lower-limb OA (4, $11,12)$.

In thumb OA, corticosteroid injections are recommended, and hyaluronic acid injections may be useful, according to the EULAR experts (5). However both of these injection modalities are not recommended by the ACR experts (4).

The objective of the present study was to assess short-term and medium-term efficacy on pain, functional capacity and pulp pinch force of intra-articular injections of corticosteroids or hyaluronic acid in patients with thumb OA in controlled trials, by performing a meta-analysis of published articles.

\section{Methods}

A systematic search was performed in PubMed Medline and EMBASE databases up to August 2013 with an update up to August 2014, without limitation of year of publication or journal, using the following keywords: ((("thumb" [MeSH Terms] OR "thumb"[All Fields]) OR ("trapeziometacarpal joint"[MeSH Terms] OR "trapeziometacarpal"[All Fields]) OR "first metacarpal-carpal"[All Fields] OR "carpometacarpal"[All Fields]) "osteoarthritis") OR "rhizarthrosis"[All Fields]) AND ("injection"[MeSH Terms] OR "injection"[All Fields] OR "injections"[All Fields]). The limits were English, French, German or Spanish language and controlled trials. In addition, the Cochrane database, reference lists of the papers initially detected to identify additional relevant reports were manually searched, as were EULAR, OARSI and ACR abstracts of the last 5 years.

Studies were initially selected on their title and abstract by one author (ST), then on their full text. All controlled trials reporting the efficacy on pain and/or functional capacity and/or pulp pinch force of intra-articular injections of corticosteroids and/or hyaluronic acid in thumb OA, were selected. For studies with incomplete data, the corresponding authors were contacted by email.

\section{Data collection:}

Using a predetermined form, the following features were collected: blinding, intention-to-treat analysis and number of participants who completed the follow-up. The Jadad scale (13) was applied to assess the methodological quality: 5 points can be awarded, with higher scores indicating higher quality. The Cochrane risk of bias tools was also applied. For each trial, demographic characteristics (sex, mean age), thumb OA features, type of corticosteroids and/or hyaluronic acid (with doses and number of injections), type of placebo if needed and duration of follow-up were collected. Pain was extracted from the studies by a $100 \mathrm{~mm}$ visual analogue scale; functional capacity was extracted as available by the following scores: Disabilities of the Arm, Shoulder and Hand (14), the Dreiser functional index (15), the Purdue Pegboard Test (16) and/or the Duruöz Hand Index (17); because functional capacity was assessed by different scores, each 
score was transformed linearly to fit the range $0-100$, in which 0 was the best situation and 100 the worst. Pulp pinch force was extracted by pulp to pulp pinch force in pounds (18).

Studies were classified according to the injection type (hyaluronic acid versus placebo, corticosteroids versus placebo and hyaluronic acid versus corticosteroids). Efficacy was assessed by the change in pain and/or functional capacity and/or pulp pinch force status between baseline and week 4, week 12 and week 24 to 26 (as available according to the studies, called week 24 in the text) in corticosteroids, hyaluronic acid and placebo groups.

\section{Statistical analysis}

In each study, the standardized response mean (SRM) was determined to assess the magnitude of treatment effect. The SRM is calculated as the mean change divided by the standard deviation of the change. Improvement was considered as a positive change. Pooled SRMs were calculated by meta-analysis, using the Mantel-Haenszel method with RevMan version 5.2 statistical software (Review Manager, Copenhagen, Denmark). Statistical heterogeneity was measured by $\mathrm{I}^{2}$. All meta-analyses were carried out with use of random effects model in case of significant heterogeneity.

\section{Results}

\section{Literature search results and trial characteristics}

Initially, 84 potentially relevant articles were screened; 76 were excluded (Figure 1). For 3 studies, the results described in the articles did not allow meta-analysis, but the studies are reported descriptively here (Table 1) (19-21). After adding 1 report from congress abstracts, 9 reports were included (Table 1) (19-27). Thus this meta-analysis included 428 patients; $168(39.2 \%)$ treated by hyaluronic acid injections, $166(38.8 \%)$ by corticosteroids injections and $94(22.0 \%)$ by placebo. Mean (standard deviation, SD) age was 63 (2.3) years and 368 patients (86\%) were females (Table 1).

The methodological quality was moderate: the mean Jadad score was 2.2 (SD 2.8) (range 1-5); 4 (67\%) trials performed intention-to-treat analyses. Of the 6 trials, 3 described precisely the patient selection or outcome, 2 used a concealed random allocation, 5 presented difference in changes with standard error of the mean and 1 with interquartile range. The Cochrane risk of bias tool also indicated moderate quality (online figure S2).

The injection was guided by X-ray in 2 studies, by ultrasound in 1 study and not guided in 3 studies. The number of injections varied across studies and sometimes across study groups (Table 1). Heterogeneity was substantial, varying between 0 and 97 for $\mathrm{I}^{2}$ across the analyses.

\section{Efficacy of corticosteroids injections versus placebo}

Mandl's study (23) indicated no difference on pain at week 24 between two groups of 62 patients with 2 injections (Table 2). Meenagh's study (24) compared 2 groups of 20 patients with one injection, and showed efficacy for corticosteroids on pain at week 24 with a large effect size (Table 2). Heyworth's study (21) indicated no difference on pain at week 24 after 2 injections between corticosteroids (22 patients) and placebo (18 patients), but the data could not be included in the meta-analysis (Table 3 ). The pooled analysis (82 patients in each arm) showed no difference between the two treatments for pain (SRM =-1.20 [-3.69; 1.29]) (online figure S1 and Table 3).

\section{Efficacy of hyaluronic acid injections versus placebo}

Roux's study (26) compared one versus three injection of hyaluronic acid with 14 patients in each group at week 12. Patients who received one injection of hyaluronic acid were considered as placebo (Table 1). It showed efficacy on pain and functional capacity at week 12 for 3 injections 
with a large effect size (Table 2). Mandl's study (23) showed efficacy of hyaluronic acid (62 patients) on functional capacity and of placebo (62 patients) on pain at week 24 (Table 2). Figen Ayhan's study (19)(not included in the meta-analysis) compared with baseline but not together 2 groups of 29 patients. It indicated lower pain and improvement of functional capacity at week 24 after one injection of hyaluronic acid. Heyworth's study (21)(not included in the meta-analysis) showed no difference on pain and functional capacity at week 12 between hyaluronic acid (20 patients) and placebo (18 patients). The pooled analyses of the studies (74 patients in each arm) showed superiority of hyaluronic acid on functional capacity $(\mathrm{SRM}=-1.14[-1.69 ;-0.60])$ but not on pain (SRM = -0.95 [-3.87; 1.97]) (online figure S1 and Table 3).

\section{Efficacy of hyaluronic acid versus corticosteroids injections}

Mandl's study (23) showed no difference between corticosteroids (62 patients) and hyaluronic acid (62 patients) on functional capacity and pain at week 24 after 2 injections (Table 2). Monfort's study (25) compared two groups (48 patients for hyaluronic acid group, 40 for corticosteroids group) who received three injections. It showed efficacy of corticosteroids on functional capacity at week 12 and 24, with no difference on pain (Table 2). Bahadir's study (22) compared two groups (20 patients in each) with one injection of corticosteroids or 3 of hyaluronic acid. It showed efficacy of hyaluronic acid on pain and functional capacity at all time points and on pulp pinch force at week 12 and 24 with large effect sizes (Table 2). Stahl's study (27) showed efficacy of corticosteroids (25 patients) on pain at week 4 and of hyaluronic acid (27 patients) on pulp pinch force at week 24 after one injection (Table 2). Fuchs' study (20)(non included in the meta-analysis) compared 2 groups of 28 patients receiving 3 injections and indicated superiority of corticosteroids until week 12 and of hyaluronic acid on week 24 on pain. For pulp pinch force no difference was evidenced. Heyworth's study (21)(not included in the meta-analysis) indicated no difference on each outcome at all time points. Finally, 157 participants with hyaluronic acid and 147 with corticosteroids were available for the comparison of pain and functional capacity and 92 for the comparison on pulp pinch force (Table 3).

The pooled analyses (Table 3) indicated no difference between hyaluronic acid and corticosteroids at short term follow-up but hyaluronic acid seemed superior on pulp pinch force status, and corticosteroids on pain at week 24 (online figure S1 and Table 3). For hyaluronic acid vs corticosteroids and pain at week 24 , the results are almost entirely driven by a strongly positive study ( $\mathrm{N}=40)$ while 3 other studies $(\mathrm{N}=274)$ found no effect.

\section{Heterogeneity}

The heterogeneity was significant for all outcomes: range of $\mathrm{I}^{2}$ over the time points was respectively $85 \%$ to $97 \%, 34 \%$ to $95 \%$ and $0 \%$ to $82 \%$ for pain, functional capacity and pulp pinch force status (online Figure S1).

\section{Discussion}

This meta-analysis found great heterogeneity in the results. Against placebo, only hyaluronic acid appeared useful. However studies comparing hyaluronic acid and corticosteroids indicated hyaluronic acid may be useful in thumb $O A$ in particular to increase functional capacity, and corticosteroid to decrease pain. These results should be further confirmed.

This study has some weaknesses. Despite the high prevalence of hand OA, there were few controlled trials in the literature, with a limited number of patients included in each. Many sources of heterogeneity were present among these studies. For example, the outcomes were heterogeneous. Pain, sometimes functional capacity and pulp pinch force were assessed, whereas the Outcome Measures in Rheumatology (OMERACT) consensus advises to evaluate 
joint activity and patient global assessment too (28). For functional capacity, each study used a different score with some tests evaluating not only the hand but the arm in its globality. Only 2 studies used a score (Dreiser functional index (15)) validated in hand OA, according to the OMERACT Hand Osteoarthritis Group (28). Length of follow up was heterogeneous too, varying from 4 to 52 weeks, making difficult the comparison between the studies, which is why 3 different endpoints were used to better model the results. The number of injections was variable as was the technique of intra-articular injection making reproductibility and pooling difficult. In one study (26), one injection of hyaluronic acid was considered as a placebo. This is based on a study realised in 1995 in knee OA which demonstrated that one injection of hyaluronic acid was no more effective than placebo. However, in the first carpo-metacarpal which is a small joint, only one injection may be sufficient. Finally, the majority of the studies used for this meta-analysis didn't have a high methodological quality highlighting the difficulties inherent to study design for injections trials.

However this study also has strengths. This review and meta-analysis is important because of the frequency of thumb OA and its impact on everyday life $(1,2,3)$. In this meta-analysis, the literature search was exhaustive, with searches in several databases and was updated over one year. The data extracted from the studies were analysed descriptively but also meta-analysed after having pooled the outcome measures in order to increase the strength of the analysis where possible. As the studies were heterogeneous in term of results and methodology, random effect models were used.

EULAR recommends intra-articular injections of corticosteroids in thumb OA but this recommendation was based on one small randomised controlled trial and one uncontrolled trial (5). Hyaluronic acid was also endorsed by the EULAR recommendations (5). The results of this meta-analysis may comfort the EULAR recommendations for hyaluronic acid and - less so - for corticosteroids. Furthermore, in knee OA, one study explored an associated injection of hyaluronic acid and corticosteroids: results were in favour of the association for the reduction of pain (30). Synergy between these 2 drugs should be more explored.

To conclude, our data suggest some benefit for hyaluronic acid and corticosteroids injections in thumb OA but the assessment of efficacy is limited by the heterogeneity of the results observed. Other controlled trials with a higher number of patients would be useful.

\section{AUTHORSHIP AND CONTRIBUTORSHIP}

All of the authors fulfil the following 4 criteria:

Substantial contributions to the conception or design of the work; or the acquisition, analysis, or interpretation of data for the work; AND

Drafting the work or revising it critically for important intellectual content; AND

Final approval of the version to be published; AND

Agreement to be accountable for all aspects of the work in ensuring that questions related to the accuracy or integrity of any part of the work are appropriately investigated and resolved.

The guarantors who accept full responsibility for the work and/or the conduct of the study, had access to the data, and controlled the decision to publish are for this paper, Sabine Trellu and Laure Gossec.

\footnotetext{
Grants: none

Competing interests:
} 
S.T., B.F. and S.D. do not have any conflicts of interest to declare.

F.B. has received fees for speaking and/or consulting from AbbVie, Pfizer, Sanofi, Expanscience, Pierre Fabre, IBSA, Genevrier, TRB Chemedica, Rottapharm, Biolberica .

L.G. has received fees for speaking and/or consulting from AbbVie, Pfizer, Janssen, MSD, Novartis, Roche-Chugai and UCB. 


\section{References}

[1] Cushnagan J, Dieppe P. Study of 500 patients with limb joint osteoarthritis. Analysis by age, sex and distribution of joint symptomatic sites. Ann Rheum Dis 1991; 50:8-13

[2] Dahaghin S, Bierma-Zeinstra SM, Reijman M et al. Prevalence and determinants of one month hand pain and hand related disability in the elderly. Ann Rheum Dis. 2005;64:99-104

[3] Zhang Y, Niu J, Kelly-Hayes M et al. Prevalence of symptomatic hand osteoarthritis and its impact on functional status among the elderly: the Framingham Study. Am J Epidemiol. 2002;156:1021-7.

[4] Hochberg MC, Altman RD, April KT et al. American College of Rheumatology 2012 recommendations for the use of nonpharmacologic and pharmacologic therapies in osteoarthritis of the hand, hip, and knee. Arthritis Care Res (Hoboken). 2012;64:465-74.

[5] Zhang W, Doherty M, Leeb BF et al. EULAR evidence based recommandations for the management of hand osteoarthritis: report of a Task Force of the EULAR Standing Commitee for International Clinical Studies Including Therapeutics (ESCISIT). Ann Rheum Dis. 2007; 66:377-88. [6] Mahendira D, Toheed TE. Systematic review of non-surgical therapies for osteoarthritis of the hand: an update. Osteoarthritis Cartilage. 2009;17:1263-8.

[7] Lo GH, LaValley M, McAlindon T et al. Intra-articular hyaluronic acid in treatment of knee osteoarthritis: a meta-analysis. JAMA. 2003;290:3115-21.

[8] Wang CT, Lin J, Chang CJ et al. Therapeutic effects of hyaluronic acid on osteoarthritis of the knee. A meta-analysis of randomized controlled trials. J Bone Joint Surg Am. 2004;86-A:358-45.

[9] Bellamy N, Campbell J, Robinson $V$ et al. Viscosupplementation for the treatment of osteoarthritis of the knee. Cochrane database Syst Rev. 2006;(2):CD005321.

[10] Bellamy N, Campbell J, Robinson V et al. Intraarticular corticosteroid for treatment of osteoarthritis of the knee. Cochrane database Syst Rev. 2006;(2):CD005328.

[11] Zhang W, Nuki G, Moskowitz RW et al. OARSI recommendations for the management of hip and knee osteoarthritis, Part III: Changes in evidence follwing systematic cumulative update of research published through January 2009. Osteoarthritis Cartilage 2010;18:476-99.

[12] Jordan KM, Arden NK, Doherty M et al. EULAR Recommendations 2003: an evidence based approach to the management of knee osteoarthritis: Report of a Task Force of the Standing Committee for International Clinical Studies Including Therapeutic Trials (ESCISIT). Ann Rheum Dis. 2003;62:1145-55.

[13] Jadad AR, Moore RA, Carroll D et al. Assessing the quality of reports of randomized clinical trials: Is blinding necessary? Control Clin Trials. 1996;17:1-12.

[14] Hudak PL, Amadio PC, Bombardier C. Development of an upper extremity outcome measure: the DASH (Disabilities of the Arm, Shoulder and Hand). The Upper Extremity Collaborative Group (UECG). Am J Ind Med 1996; 29:602-8.

[15] Dreiser RL, Maheu E, Guillou GB et al. Validation of an algofunctional index for osteoarthritis of the hand. Rev Rhum Eng Ed. 1995;62(6 Suppl 1):43S-53S.

[16] Desrosiers J, Hébert G, Bravo G et al. The Purdue Pegboard Test: normative data for people aged 60 and over. Disabil Rehabil. 1995;17:217-24.

[17] Duruöz MT, Poiraudeau S, Fermanian J et al. Development and validation of a rheumatoid hand functional disability scale that assesses functional handicap. J Rheumatol. 1996;23:1167-72.

[18] Mathiowetz V, Weber K, Volland G et al. Reliability and validity of grip and pinch strength evaluations. J Hand Surg Am. 1984;9:222-6.

[19] Figen Ayhan F, Ustun N. The evaluation of efficacy and tolerability of hylan G-F 20 in bilateral tjumb base osteoarthritis: 6 months follow-up. Clin Rheumatol 2009;28:535-541.

[20] Fuchs S, Mönikes R, Wohlmeiner A et al. Intra-articular hyaluronic acid compared with corticoid injections for the treatment of rhizarthrosis. Osteoarthritis Cartilage 2006;14:82-88.

[21] Heyworth BE, Lee JH, Kim PD et al. Hylan versus corticosteroid versus placebo for the treatment of basal joint arthritis: a prospective, randomized, double-blinded clinical trial. J Hand Surg Am 2008;33:40-8. 
[22] Bahadir C, Onal B, Dayan VY et al. Comparison of therapeutic effects of sodium hyaluronate and corticosteroid injections on trapeziometacarpal joint osteoarthritis. Clin Rheumatol 2009;28:529-33.

[23] Mandl LA, Wolfe S, Daluiski A et al. A Randomized Controlled Trial of Hylan G-F 20 for the Treatment of Carpometacarpal Osteoarthritis. Arthritis Rheum 2012;64(10 Suppl):S475-76.

[24] Meenagh GK, Patton J, Kynes C et al. A randomised controlled trial of intra-artcular corticosteroid injection of the carpometacarpal joint of the thumb osteoarthritis. Ann Rheum Dis 2004;63:1260-1263.

[25] Monfort J, Rotes D, Montanes F et al. Comparative efficacy of intra-articular hyaluronic acid and corticoid injections in osteoarthritis of the first carpometacarpal joint: Results of a 6-month single-masked randomized study.

Joint Bone Spine 2014 doi: 10.1016/j.jbspin.2014.08.008

[26] Roux C, Fontas E, Breuil V et al. Injection of intra-articular sodium hyaluronate (Sinovial@) into the carpometacarpal joint of the thumb (CMC1) in osteoarthitis. A prospective evaluation of efficacy. Joint Bone Spine 2007;74:368-372.

[27] Stahl S, Karsh-Zafrir I, Ratzon N et al. Comparison of intraarticular injection of depot corticosteroid and hyaluronic acid for treatment of degenerative trapeziometacarpal joints. J Clin Rheumatol 2005;11:299-302.

[28] Kloppenburg M, Boyesen P, Smeets W et al. Report from the OMERACT Hand Osteoarthritis Special Interst Group: advances and future research priorities. J Rheumatol. 2014;41:810-8.

[29] Bannuru RR, Natov NS, Dasi UR et al. Therapeutic trajectory following intra-articular hyaluronic acid injection in knee osteoarthritis -- meta-analysis. Osteoarthritis Cartilage 2011;19:611-619.

[30] Grecomoro G, Piccione F, Letizia G. Therapeutic synergism between hyaluronic acid and dexamethasone in the intra-articular treatment of the osteoarthritis of the knee: a preliminary open study. Curr Med Res Opin. 1992;13: 49-55.

Figure 1 Flow chart

Table 1 Baseline characteristics of patients in randomised controlled trials of intra-articular injections in thumb osteoarthritis.

Table 2 Standardised response means in controlled trials comparing intra-articular injections on pain, functional capacity and/or pulp pinch force status in patients with thumb osteoarthritis.

Table 3 Pooled standardised response mean for intra-articular injections in thumb osteoarthritis

\section{Online supplement only Figure $\mathbf{S 1}$}

A: Comparison placebo versus corticosteroids;

B: comparison placebo versus hyaluronic acid,

C: comparison corticosteroids versus hyaluronic acid.

\section{Online supplement only Figure S2}

Cochrane risk of bias tool 
Figure 1: Flow chart

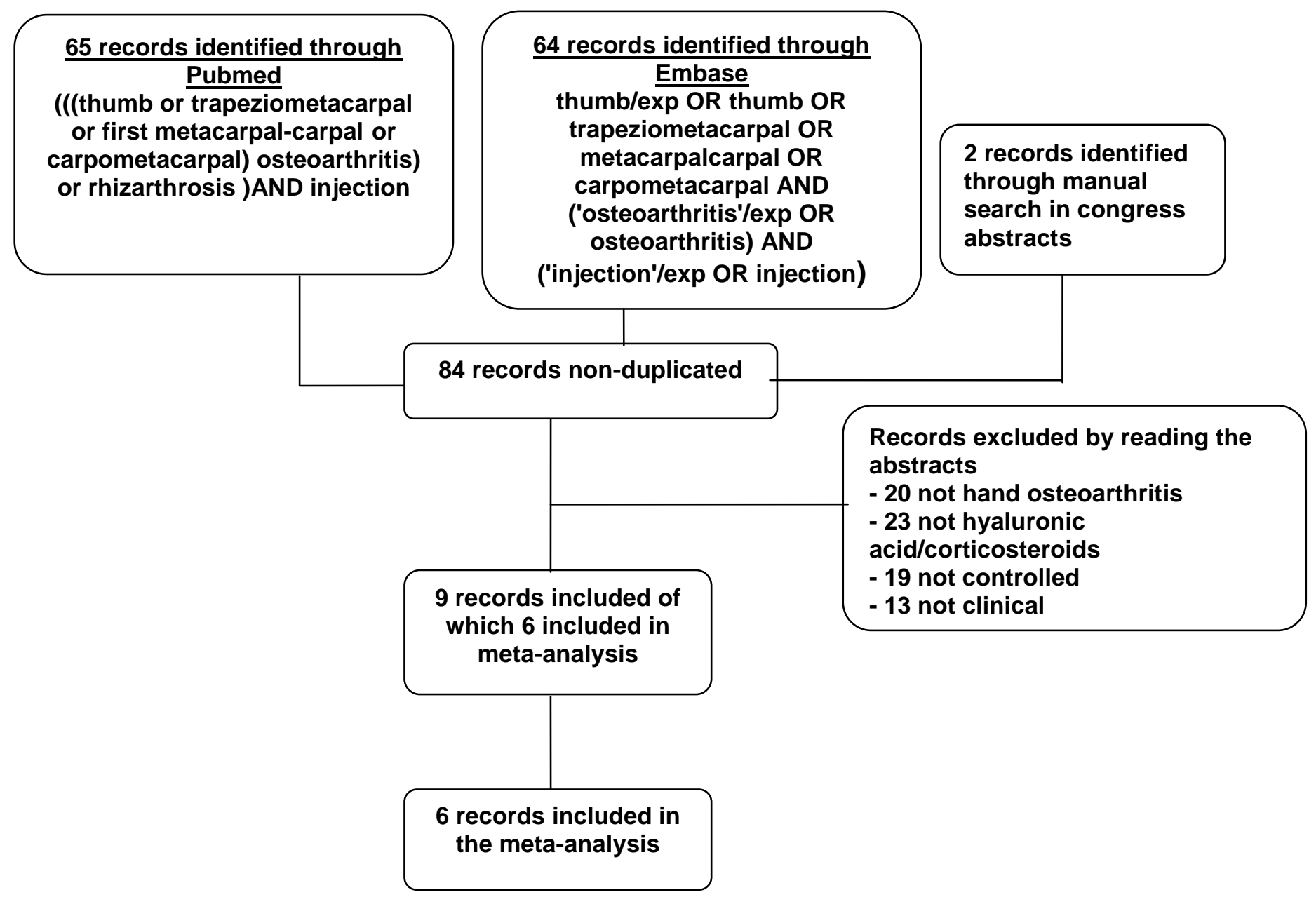


Table 1 Baseline characteristics of patients in randomised controlled trials of intra-articular injections in thumb osteoarthritis.

\begin{tabular}{|c|c|c|c|c|c|c|c|c|}
\hline $\begin{array}{l}\text { Study, } \\
\text { publication year }\end{array}$ & Intervention & $\begin{array}{l}\text { Number of } \\
\text { injections }\end{array}$ & $\begin{array}{l}\text { Study } \\
\text { Duration } \\
\text { (weeks) }\end{array}$ & $\begin{array}{l}\text { Number } \\
\text { of } \\
\text { patients }\end{array}$ & $\begin{array}{l}\text { Women } \\
(\%)\end{array}$ & $\begin{array}{l}\text { Mean age } \pm \\
\text { SD or (min- } \\
\text { max) } \\
\text { (years) }\end{array}$ & $\begin{array}{l}\text { Guidance } \\
\text { of the } \\
\text { injection }\end{array}$ & $\begin{array}{l}\text { Jadad } \\
\text { score }\end{array}$ \\
\hline
\end{tabular}

\begin{tabular}{|c|c|c|c|c|c|c|c|}
\hline $\begin{array}{l}\text { Bahadir et al (22), } \\
2009\end{array}$ & $\begin{array}{l}\text { - TA (20mg/0.5ml) } \\
\text { - SH (5mg/0.5ml) }\end{array}$ & $\begin{array}{l}-1 \text { for TA } \\
-3 \text { weekly for } \\
\text { SH }\end{array}$ & 52 & 40 & $\begin{array}{l}40 \\
(100)\end{array}$ & $61.8 \pm 8.2$ & None \\
\hline
\end{tabular}

\begin{tabular}{|c|c|c|c|c|c|c|c|c|}
\hline $\begin{array}{l}\text { Mandl et al (23), } \\
2012\end{array}$ & $\begin{array}{l}\text { - TA }(40 \mathrm{mg} / 1 \mathrm{ml}) \text { puis } \\
1 \mathrm{ml} 0.5 \% \text { bupivacaine } \\
\text { - Hylan G-F } 201 \mathrm{ml} \\
\text { - Bupivacaine } 1 \mathrm{ml} 0.5 \%\end{array}$ & 2 & 26 & 188 & $\begin{array}{l}127 \\
(67.7)\end{array}$ & $\begin{array}{l}66.5 \\
(45-89)\end{array}$ & None & 1 \\
\hline 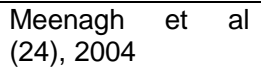 & $\begin{array}{l}\text { - TA }(5 \mathrm{mg} / 0.25 \mathrm{ml}) \\
\text { - Saline } 0.25 \mathrm{ml}\end{array}$ & 1 & 24 & 40 & $\begin{array}{l}36 \\
(90)\end{array}$ & $\begin{array}{l}59.9 \\
(41-71)\end{array}$ & X-ray & 5 \\
\hline
\end{tabular}

\begin{tabular}{|c|c|c|c|c|c|c|c|c|}
\hline $\begin{array}{l}\text { Monfort et al (25), } \\
2014\end{array}$ & $\begin{array}{l}\text { - Bethametasone } \\
(1.5 \mathrm{mg} / 0.5 \mathrm{ml}) \\
\text { - Suplasyn }(5 \mathrm{mg} / 0.5 \mathrm{ml})\end{array}$ & 3 & 24 & 88 & $\begin{array}{l}77 \\
(87.5)\end{array}$ & $62.8 \pm 8.7$ & ultrasound & 3 \\
\hline $\begin{array}{l}\text { Roux et al (26), } \\
2007\end{array}$ & - $\mathrm{SH} 1 \mathrm{ml}$ & $\begin{array}{l}-3 \text { for } \mathrm{SH} \\
-1 \text { for } \\
\text { placebo }\end{array}$ & 12 & 42 & $\begin{array}{l}38 \\
(90.5)\end{array}$ & $64.8 \pm 8.0$ & X-ray & 2 \\
\hline $\begin{array}{l}\text { Stahl et al (27), } \\
2005\end{array}$ & $\begin{array}{l}\text { - SH }(15 \mathrm{mg} / \mathrm{ml}) \\
\text { - Methylprednisolone } \\
\text { acetate }(40 \mathrm{mg} / \mathrm{ml})\end{array}$ & 1 & 24 & 52 & $\begin{array}{l}46 \\
(88)\end{array}$ & $\begin{array}{l}62 \\
(37-91)\end{array}$ & None & 2 \\
\hline $\begin{array}{l}\text { Fuchs et al (20), } \\
2006 \\
\text { Not included in } \\
\text { meta-analysis }\end{array}$ & $\begin{array}{l}\text {-Sodium hyaluronate, } \\
1 \mathrm{ml} \\
-\mathrm{TA}, 1 \mathrm{ml}\end{array}$ & 3 & 26 & 56 & $\begin{array}{l}45 \\
(75)\end{array}$ & 60.25 & None & 1 \\
\hline
\end{tabular}

SD: standard deviation. TA: triamcinolone acetonide. SH: sodium hyaluronate 
Table 2 Standardised response mean of controlled trials comparing injections for pain, functional capacity and/or pulp pinch force status in patients with hand osteoarthritis.

\begin{tabular}{|c|c|c|c|c|c|c|}
\hline Reference & $\begin{array}{l}\text { Type } \\
\text { of injection }\end{array}$ & Comparator & Outcome measure & Week 4 & Week 12 & Week 24 \\
\hline \multirow{3}{*}{$\begin{array}{c}\text { Bahadir } \\
\text { et } \\
\text { al (2009) (22) }\end{array}$} & \multirow{3}{*}{$\begin{array}{l}\text { Triamcinolone } \\
\text { acetonide }\end{array}$} & \multirow{3}{*}{$\begin{array}{l}\text { Sodium } \\
\text { Hyaluronate }\end{array}$} & Pain & $\begin{array}{c}1.19 \\
{[0.51 ; 1.87]}\end{array}$ & $\begin{array}{c}1.38 \\
{[0.68 ; 2.07]}\end{array}$ & $\begin{array}{c}9.31 \\
{[7.07 ; 11.55]}\end{array}$ \\
\hline & & & $\begin{array}{l}\text { Functional capacity } \\
(\mathrm{DHI})\end{array}$ & $\begin{array}{c}3.64 \\
{[2.60 ; 4.69]}\end{array}$ & $\begin{array}{c}1.95 \\
{[1.18 ; 2.71]}\end{array}$ & $\begin{array}{c}2.39 \\
{[1.56 ; 3.22]}\end{array}$ \\
\hline & & & $\begin{array}{l}\text { Pulp pinch force } \\
\text { status }\end{array}$ & $\begin{array}{c}0.38 \\
{[-0.24 ; 1.01]}\end{array}$ & $\begin{array}{c}1.03 \\
{[0.37 ; 1.69]}\end{array}$ & $\begin{array}{c}2.16 \\
{[1.37 ; 2.96]}\end{array}$ \\
\hline \multirow{5}{*}{$\begin{array}{c}\text { Mandl } \\
\text { et } \\
\text { al (2012) (23) }\end{array}$} & \multirow{2}{*}{$\begin{array}{l}\text { Triamcinolone } \\
\text { acetonide }\end{array}$} & \multirow{2}{*}{$\begin{array}{l}\text { Hylan } \\
\text { G-F } 20\end{array}$} & Pain & NA & NA & $\begin{array}{c}0.15 \\
{[-0.21 ; 0.50]}\end{array}$ \\
\hline & & & $\begin{array}{l}\text { Functional } \\
\text { capacity (DASH) }\end{array}$ & NA & NA & $\begin{array}{c}-0.66 \\
{[-1.02 ; 0.30]}\end{array}$ \\
\hline & $\begin{array}{l}\text { Triamcinolone } \\
\text { acetonide }\end{array}$ & Bupivacaine & Pain & NA & NA & $\begin{array}{c}0.04 \\
{[-0.31 ; 0.39]}\end{array}$ \\
\hline & \multirow{2}{*}{ Hylan G-F 20} & \multirow{2}{*}{ Bupivacaine } & Pain & NA & NA & $\begin{array}{c}0.49 \\
{[0.13 ; 0.85]}\end{array}$ \\
\hline & & & $\begin{array}{l}\text { Functional } \\
\text { capacity (DASH) }\end{array}$ & NA & NA & $\begin{array}{c}-0.98 \\
{[-1.35 ;-0.60]}\end{array}$ \\
\hline $\begin{array}{c}\text { Meenagh } \\
\text { et } \\
\text { al (2004) (24) }\end{array}$ & $\begin{array}{l}\text { Triamcinolone } \\
\text { acetonide }\end{array}$ & Saline & Pain & NA & NA & $\begin{array}{c}-2.50 \\
{[-3.35 ;-1.65]}\end{array}$ \\
\hline \multirow{2}{*}{$\begin{array}{c}\text { Montfort } \\
\text { et } \\
\text { al } 2014(25)\end{array}$} & \multirow{2}{*}{$\begin{array}{l}\text { Betamethasone } \\
\text { acetate }\end{array}$} & \multirow{2}{*}{ Suplasyn® } & Pain & $\begin{array}{c}0,23 \\
{[-0.20 ; 0.65]}\end{array}$ & $\begin{array}{c}-0.03 \\
{[-0.44 ; 0.39]}\end{array}$ & $\begin{array}{c}-0.21 \\
{[-0.63 ; 0.21]}\end{array}$ \\
\hline & & & $\begin{array}{l}\text { Functional capacity } \\
\text { (Dreiser) }\end{array}$ & $\begin{array}{c}0.00 \\
{[-0.42 ; 0.42]}\end{array}$ & $\begin{array}{c}-0.75 \\
{[-1.19 ;-0.32]}\end{array}$ & $\begin{array}{c}-0.47 \\
{[-0.90 ;-0.05]}\end{array}$ \\
\hline \multirow{2}{*}{$\begin{array}{c}\text { Roux } \\
\text { et } \\
\text { al (2007) (26) }\end{array}$} & \multirow{2}{*}{$\begin{array}{l}\text { Sodium } \\
\text { hyaluronate } \\
\text { (3 injections) }\end{array}$} & \multirow{2}{*}{$\begin{array}{l}\text { Sodium } \\
\text { Hyaluronate } \\
\text { (1 injection) }\end{array}$} & Pain & NA & $\begin{array}{c}-2.49 \\
{[-3.60 ;-1.38]}\end{array}$ & NA \\
\hline & & & $\begin{array}{l}\text { Functional } \\
\text { capacity (Dreiser) }\end{array}$ & NA & $\begin{array}{c}-1.61 \\
{[-2.56 ;-0.67]}\end{array}$ & NA \\
\hline \multirow{3}{*}{$\begin{array}{c}\text { Stahl } \\
\text { et } \\
\text { al (2005) (27) }\end{array}$} & \multirow{3}{*}{$\begin{array}{l}\text { Methylprednisolo } \\
\text { ne acetate }\end{array}$} & \multirow{3}{*}{$\begin{array}{l}\text { Sodium } \\
\text { Hyaluronate }\end{array}$} & Pain & $\begin{array}{l}-0.90 \\
{[-1.47 ;-0.33]}\end{array}$ & $\begin{array}{c}-0.13 \\
{[-0.68 ; 0.41]}\end{array}$ & $\begin{array}{c}0.00 \\
{[-0.54 ; 0.54]}\end{array}$ \\
\hline & & & $\begin{array}{l}\text { Functional } \\
\text { capacity (PPT) }\end{array}$ & $\begin{array}{c}0.00 \\
{[-0.54 ; 0.54]}\end{array}$ & $\begin{array}{c}0.00 \\
{[-0.54 ; 0.54]}\end{array}$ & $\begin{array}{c}-0.19 \\
{[-0.77 ; 0.35]}\end{array}$ \\
\hline & & & $\begin{array}{l}\text { Pulp pinch } \\
\text { force status }\end{array}$ & $\begin{array}{c}0.00 \\
{[-0.54 ; 0.54]}\end{array}$ & $\begin{array}{c}0.00 \\
{[-0.54 ; 0.54]}\end{array}$ & $\begin{array}{c}1.23 \\
{[0.63 ; 1.83]}\end{array}$ \\
\hline
\end{tabular}

NA: not available. DASH: Disability of the Arm, Shoulder and Hand (14). Dreiser: Dreiser functional index (15). PPT: Purdue Pegboard Test (16). DHI: Durüoz Hand Index (17). Significant results are in bold type. 
Table 3 Pooled SRMs for intra-articular injections in thumb osteoarthritis

\begin{tabular}{|c|c|c|c|c|}
\hline Type of injection & Outcome measure & Week 4 & Week 12 & Week 24 \\
\hline $\begin{array}{l}\text { Corticosteroids vs } \\
\text { placebo }\end{array}$ & Pain & NE & NE & $-1.20[-3.69 ; 1.29]$ \\
\hline \multirow{2}{*}{$\begin{array}{l}\text { Hyaluronic acid vs } \\
\text { placebo }\end{array}$} & Pain & NE & $-0.95[-3.97 ; 1.97]$ & NE \\
\hline & Functional capacity & NE & $-1.14[-1.69 ;-0.60]$ & NE \\
\hline \multirow{3}{*}{$\begin{array}{l}\text { Hyaluronic acid vs } \\
\text { corticosteroids }\end{array}$} & Pain & $0.16[-0.89 ; 1.21]$ & $0.37[-0.45 ; 1.18]$ & $1.44[0.14 ; 2.74]$ \\
\hline & Functional capacity & $1.13[-0.49 ; 2.73]$ & $0.36[-1.02 ; 1.75]$ & $0.20[-0.77 ; 1.16]$ \\
\hline & Pulp pinch force & $0.17[-0.25 ; 0.58]$ & $0.50[-0.51 ; 1.50]$ & $-1.66[-0.75 ;-2.57]$ \\
\hline
\end{tabular}

Significant results are in bold type

NE: not estimable 
Online supplement only figure S1 A: Comparison placebo versus corticosteroids; B: comparison placebo versus hyaluronic acid, C: comparison corticosteroids versus hyaluronic acid.

A. Comparison corticosteroids versus placebo. Outcome Pain at week 24

\begin{tabular}{|lcccc|}
\hline Study & $\begin{array}{c}\text { Corticosteroids } \\
\text { N }\end{array}$ & $\begin{array}{c}\text { Placebo } \\
\text { N }\end{array}$ & $\begin{array}{c}\text { Std. Mean Difference } \\
\text { IV, Random, 95\% Cl IV, Random, 95\% Cl }\end{array}$ \\
\hline Mandl 2012 & 62 & 62 & $0.04[-0.31,0.39]$ \\
Meenagh 2004 & 20 & 20 & $-2.50[-3.35,-1.65]$ \\
Total (95\% Cl) & 82 & 82 & $-1.20[-3.69,1.29]$ \\
I $^{2}=97 \%$ & & & Favours [Corticosteroids] Favours [Placebo]
\end{tabular}

B. Comparison hyaluronic acid versus placebo. Outcome Functional capacity at week 12

\begin{tabular}{|c|c|c|c|c|}
\hline Study & ronic acid & $\begin{array}{l}\text { Placebo } \\
\mathrm{N}\end{array}$ & $\begin{array}{l}\text { Std. Mean Difference } \\
\text { IV, Random, } 95 \% \mathrm{Cl}\end{array}$ & $\begin{array}{l}\text { Std. Mean Difference } \\
\text { IV, Random, } 95 \% \mathrm{Cl}\end{array}$ \\
\hline Mandl 2012 & 62 & 62 & $-0.98[-1.35,-0.60]$ & \\
\hline Roux 2007 & 12 & 12 & $-1.61[-2.56,-0.67] \square$ & \\
\hline Total $(95 \% \mathrm{Cl})$ & 74 & 74 & $-1.14[-1.69,-0.60]$ & \\
\hline$I^{2}=34 \%$ & & & $\begin{array}{cc}-4 & -2 \\
\text { Favours [hyaluronic }\end{array}$ & $\begin{array}{ccc}0 & 2 & 4 \\
\text { cid] Favours [Placebo] }\end{array}$ \\
\hline
\end{tabular}

Comparison hyaluronic acid versus placebo. Outcome: Pain at week 12

\begin{tabular}{|c|c|c|c|c|}
\hline Study & $\begin{array}{l}\text { ronic acid } \\
\mathrm{N}\end{array}$ & $\begin{array}{c}\text { Placebo } \\
\mathrm{N}\end{array}$ & Sty, Radomffeséned & $\begin{array}{l}\text { Std. Mean Difference } \\
\text { IV, Random, } 95 \% \mathrm{CI}\end{array}$ \\
\hline Mandl 2012 & 62 & 62 & $0.49[0.13,0.85]$ & 五 \\
\hline Roux 2007 & 62 & 12 & $-2.49[-3.60,-1.38]$ & \\
\hline Total $(95 \% \mathrm{Cl})$ & 74 & 74 & $-0.95[-3.87,1.97]$ & \\
\hline$I^{2}=96 \%$ & & & $\begin{array}{cc} & 1 \\
-4 & -2 \\
\text { Favours [hyaluronic }\end{array}$ & $\begin{array}{ccc}0 & 2 & 4 \\
\text { cid] } & \text { Favours [Placebo] }\end{array}$ \\
\hline
\end{tabular}


C. Comparison of hyaluronic acid versus corticosteroids. Outcome: Pain at week 4

\begin{tabular}{|c|c|c|c|c|}
\hline \multirow[b]{2}{*}{ Study } & nic : & steroids & \multirow{2}{*}{$\begin{array}{l}\text { Std. Mean Difference } \\
\text { IV, Random, } 95 \% \mathrm{Cl}\end{array}$} & \multirow{2}{*}{$\begin{array}{l}\text { Std. Mean Difference } \\
\text { IV, Random, } 95 \% \mathrm{CI}\end{array}$} \\
\hline & $\mathrm{N}$ & $\mathrm{N}$ & & \\
\hline Bahadir 2009 & 20 & 20 & $1.19[0.51,1.87]$ & $千-$ \\
\hline Monfort & 48 & 40 & $0.23[-0.20,0.65]$ & $t$ \\
\hline Stahl 2005 & 27 & 25 & $-0.90[-1.47,-0.33] \rightarrow \square$ & \\
\hline Total (95\% Cl) & 95 & 85 & $0.16[-0.89,1.21]$ & \\
\hline$F^{2}=91 \%$ & & & 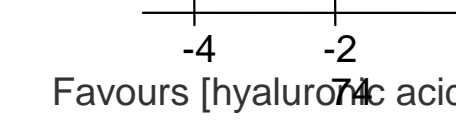 & $\begin{array}{ccc}0 & 2 & 4 \\
\text { d] Favours [corticosteroids] }\end{array}$ \\
\hline
\end{tabular}

Comparison of hyaluronic acid versus corticosteroids. Outcome: Pain at week 12

\begin{tabular}{|c|c|c|c|c|}
\hline \multicolumn{3}{|c|}{ Hyaluronic acid Corticoseroids } & Std. Mean Difference & \multirow{2}{*}{$\begin{array}{l}\text { Std. Mean Difference } \\
\text { IV, Random, } 95 \% \mathrm{Cl}\end{array}$} \\
\hline Study & $\mathrm{N}$ & $\mathrm{N}$ & IV, Random, 95\% Cl & \\
\hline Bahadir 2009 & 20 & 20 & $1.38[0.68,2.07]$ & $\square \square$ \\
\hline Monfort & 48 & 40 & $-0.03[-0.44,0.39]$ & \\
\hline Stahl 2005 & 27 & 25 & $-0.13[-0.68,0.41]$ & \\
\hline Total $(95 \% \mathrm{Cl})$ & 95 & 85 & $0.37[-0.45,1.18]$ & \\
\hline$F^{2}=85 \%$ & & & $\begin{array}{cc}-4 & -2 \\
\text { Favours [hyaluronic ac }\end{array}$ & $\begin{array}{ccc}0 & 2 & 4 \\
\text { cid] } & \text { Favours [corticoster }\end{array}$ \\
\hline
\end{tabular}

Comparison of hyaluronic acid versus corticosteroids. Outcome: Pain at week 24

\begin{tabular}{|c|c|c|c|c|}
\hline Hyal & \multicolumn{2}{|c|}{ Hyaluronic acid Corticosteroids } & $\begin{array}{l}\text { Std. Mean Difference } \\
\text { IV, Random, } 95 \% \mathrm{Cl}\end{array}$ & $\begin{array}{l}\text { Std. Mean Difference } \\
\text { IV, Random, } 95 \% \mathrm{Cl}\end{array}$ \\
\hline Bahadir 2009 & 20 & 20 & $9.31[7.07,11.55]$ & $\begin{array}{l}- \\
\end{array}$ \\
\hline Mandl 2012 & 62 & 62 & $0.15[-0.21,0.50]$ & 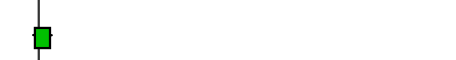 \\
\hline Monfort & 48 & 40 & $-0.21[-0.63,0.21]$ & 란 \\
\hline Stahl 2005 & 27 & 25 & $0.00[-0.54,0.54]$ & 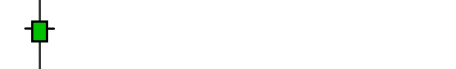 \\
\hline Total $(95 \% \mathrm{Cl})$ & 157 & 147 & $1.44[0.14,2.74]$ & \\
\hline$I^{2}=96 \%$ & & & $\begin{array}{cc}-10 & -5 \\
\text { Favours [hyaluronic a }\end{array}$ & $\begin{array}{ccc}0 & 5 & 10 \\
\text { d] Favours [corticosteroids }\end{array}$ \\
\hline
\end{tabular}

Comparison of hyaluronic acid versus corticosteroids. Outcome: Functional capacity at week 4

\begin{tabular}{|c|c|c|c|c|}
\hline \multirow[b]{2}{*}{ Study } & \multicolumn{3}{|c|}{ Hyaluronic acid Corticosteroids Std. Mean Difference } & \multirow{2}{*}{$\begin{array}{l}\text { Std. Mean Difference } \\
\text { IV, Random, } 95 \% \mathrm{Cl}\end{array}$} \\
\hline & $\mathrm{N}$ & $\mathrm{N}$ & IV, Random, 95\% Cl & \\
\hline Bahadir 2009 & 20 & 20 & $3.64[2.60,4.69]$ & $\square$ \\
\hline Monfort & 48 & 40 & $0.00[-0.42,0.42]$ & $-t$ \\
\hline Stahl 2005 & 27 & 25 & $0.00[-0.54,0.54]$ & \\
\hline Total $(95 \% \mathrm{Cl})$ & 95 & 85 & $1.13[-0.49,2.75]$ & \\
\hline$F^{2}=95 \%$ & & & -4 & 0 \\
\hline
\end{tabular}

Favours [hyaluronic acid] Favours [corticosteroids] 
Comparison of hyaluronic acid versus corticosteroids. Outcome: Functional capacity at week 12

\begin{tabular}{|c|c|c|c|c|}
\hline \multirow[b]{2}{*}{ Study } & \multicolumn{2}{|c|}{ Hyaluronic acid Corticosteroids } & \multirow{2}{*}{$\begin{array}{l}\text { Std. Mean Difference } \\
\text { IV, Random, } 95 \% \mathrm{Cl}\end{array}$} & \multirow{2}{*}{$\begin{array}{l}\text { Std. Mean Difference } \\
\text { IV, Random, } 95 \% \mathrm{Cl}\end{array}$} \\
\hline & $\mathrm{N}$ & $\mathrm{N}$ & & \\
\hline Bahadir 2009 & 20 & 20 & $1.95[1.18,2.71]$ & $\square$ \\
\hline Monfort & 48 & 40 & $-0.75[-1.19,-0.32]-\square$ & \\
\hline Stahl 2005 & 27 & 25 & $0.00[-0.54,0.54]$ & \\
\hline Total $(95 \% \mathrm{Cl})$ & 95 & 85 & $0.36[-1.02,1.75]$ & \\
\hline$\left.\right|^{2}=94 \%$ & & & $\begin{array}{cc}-4 & -2 \\
\text { Favours [hyaluronic ac }\end{array}$ & $\begin{array}{ccc}0 & 2 & 4 \\
\text { d] Favours [corticosteroid }\end{array}$ \\
\hline
\end{tabular}

Comparison of hyaluronic acid versus corticosteroids. Outcome: Functional capacity at week 24

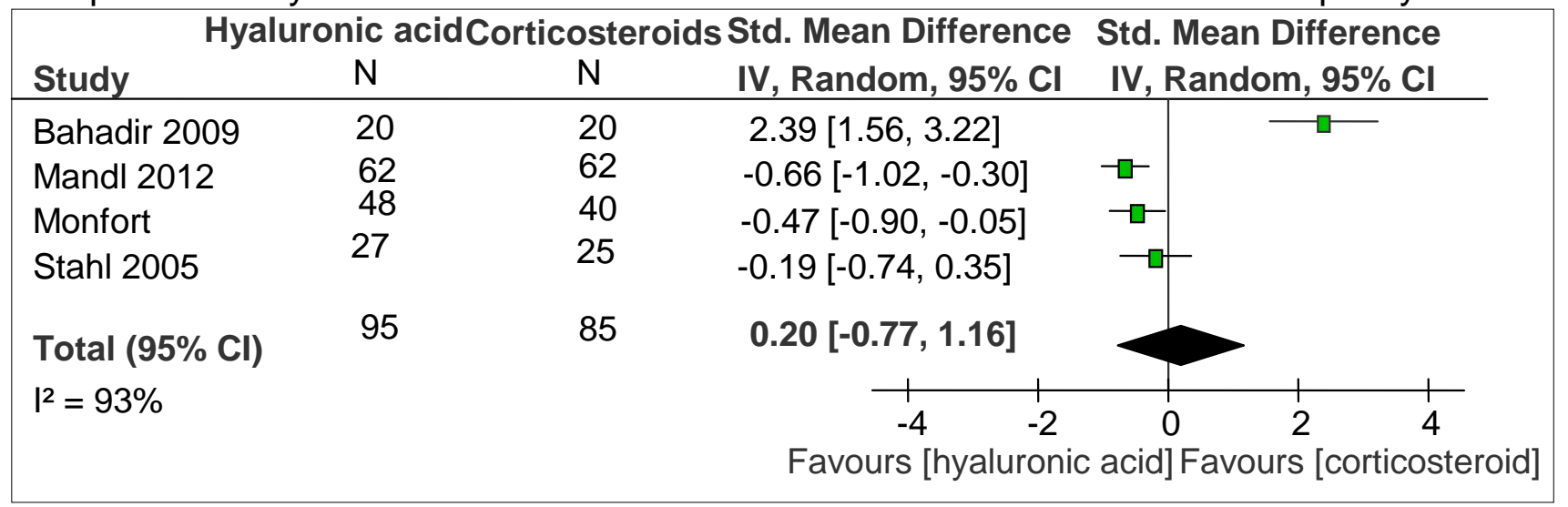

Comparison of hyaluronic acid versus corticosteroids. Outcome: Pulp pinch force at week 4

\begin{tabular}{|c|c|c|c|c|}
\hline \multirow[t]{2}{*}{ Hyalı } & \multicolumn{3}{|c|}{ Iyaluronic acidCorticosteroidsStd. Mean Difference } & \multirow{2}{*}{$\begin{array}{l}\text { Std. Mean Difference } \\
\text { IV, Random, } 95 \% \mathrm{Cl}\end{array}$} \\
\hline & $\mathrm{N}$ & $\mathrm{N}$ & IV, Random, 95\% Cl & \\
\hline Bahadir 2009 & 20 & 20 & $0.38[-0.24,1.01]$ & \\
\hline Stahl 2005 & 27 & 25 & $0.00[-0.54,0.54]$ & \\
\hline Total $(95 \% \mathrm{Cl})$ & 47 & 45 & $0.17[-0.25,0.58]$ & \\
\hline$I^{2}=0 \%$ & & & $\begin{array}{cc}-4 & -2 \\
\text { Favours [corticoste }\end{array}$ & $\begin{array}{ccc}0 & 1 & 4 \\
\text { ds] Favours [hyaluron }\end{array}$ \\
\hline
\end{tabular}

Comparison of hyaluronic acid versus corticosteroids. Outcome: Pulp pinch force at week 12

\begin{tabular}{|c|c|c|c|c|}
\hline \multicolumn{4}{|c|}{ Hyaluronic acid Corticosteroids Std. Mean Difference } & \multirow{2}{*}{$\begin{array}{l}\text { Std. Mean Difference } \\
\text { IV, Random, } 95 \% \mathrm{Cl}\end{array}$} \\
\hline Study & $\mathrm{N}$ & $\mathrm{N}$ & IV, Random, 95\% Cl & \\
\hline Bahadir 2009 & 20 & 20 & $1.03[0.37,1.69]$ & $\sqrt{-5}$ \\
\hline Stahl 2005 & 27 & 25 & $0.00[-0.54,0.54]$ & \\
\hline Total $(95 \% \mathrm{Cl})$ & 47 & 45 & $0.50[-0.51,1.50]$ & \\
\hline$I^{2}=82 \%$ & & & $\begin{array}{cc}-4 & -2 \\
\text { Favours [corticoste }\end{array}$ & $\begin{array}{ccc}0 & 2 & 4 \\
\text { s] Favours [hyaluronic }\end{array}$ \\
\hline
\end{tabular}

